\title{
PENERAPAN PENDEKATAN SAINTIFIK UNTUK MENINGKATKAN KREATIVITAS DAN HASIL BELAJAR SISWA DALAM MATA PELAJARAN IPA
}

\author{
Nur Alamsyah \\ (Teknologi Pembelajaran Pascasarjana Unesa) \\ E-mail (nuralamsyah_haq@yahoo.com)
}

\begin{abstract}
Abstrak
Penelitian ini bertujuan untuk mendeskripsikan penerapan pendekatan saintifik untuk meningkatkan kreativitas dan hasil belajar siswa dalam mata pelajaran IPA kelas V SD Negeri 12/30 Kanaungan Kabupaten Pangkep . dengan penerapan pendekatan saintifik maka kreativitas dan hasil belajar siswa dapat meningkat.

Penelitian ini merupakan Penelitian Tindakan Kelas (PTK) yang dilaksanakan tiap siklus pembelajaran terdiri atas (1) Perencanaan (2) Pelaksanaan (3) Observasi dan (4) Refleksi. Perangkat pembelajaran yang digunakan meliputi silabus, rencana pelaksanaan pembelajaran (RPP), lembar kerja siswa (LKS), buku siswa, lembar evaluasi. Instrumen meliputi Lembar Pengamatan keterlaksanaan guru mengelola pembelajaran, Lembar aktivitas siswa mengikuti pembelajaran serta angket respon siswa terhadap pembelajaran yang diikutinya. Kurikulum yang digunakan dalam penelitian ini adalah kurikulum tingkat satuan pendidikan (KTSP) tahun 2006 dengan materi pokok bumi dan alam semesta. Adapun data yang dianalisis sebagai hasil penelitian meliputi: (1) Keterlaksanaan guru dalam mengelola pembelajaran dan aktivitas siswa mengikuti pembelajaran (2) Kreativitas siswa (3), Hasil belajar siswa (4), Respon siswa terhadap pembelajaran yang diikutinya.

Dari hasil analisis data selama tiga siklus menunjukkan bahwa: (1) keterlaksanaan guru dalam mengelola pembelajaran mencapai tingkat persentase ketercapaian $84 \%$ atau ada pada kategori "sangat baik (2) aktivitas siswa mengikuti pembelajaran mencapai kategori "efektif",(3) kreativitas siswa menunjukkan $100 \%$ siswa kreatif, (4) hasil belajar siswa ranah kognitif dengan rata-rata kelas 84 ranah sikap dengan rata-rata 88 , dan ranah psikomotor dengan rata-rata 81 dengan kategori tuntas, dan ketuntasan individu mencapai 92\% dengan kategori "tuntas", (5) Respon siswa dalam mengikuti pembelajaran mencapai tingkat "positif" atau pada kategori (Senang, Baru, Menarik, dan Ya).

Berdasarkan pembahasan hasil penelitian dan analisis data dapat disimpulkan bahwa terdapat peningkatan kreativitas dan hasil belajar siswa terhadap penerapan pendekatan saintifik.
\end{abstract}

Kata Kunci: Pendekatan Saintifik, Kreativitas, Hasil Belajar.

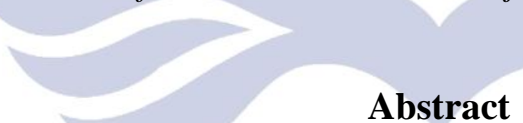

This study aimed to describe the application of scientific approaches to promote creativity and student learning outcomes in science class V SDN 12/30 Kanaungan Pangkep. with the application of the scientific approach to creativity and student learning outcomes can be improved.

This research is a classroom action research (PTK) held every learning cycle consists of (1) Planning (2) Execution (3) Observation and (4) reflection. Learning tools used include the syllabus, lesson plan (RPP), student worksheet (LKS), student books, sheet evaluation. Instruments include keterlaksanaan Observation Sheet teachers manage learning, student activity sheet to follow the teaching and learning of the student questionnaire responses that followed. The curriculum used in this study is the education unit level curriculum (SBC) in 2006 with the subject matter of the earth and the universe. The data were analyzed as a result of the study include: (1) Keterlaksanaan teachers in managing learning and learning activities of students attend (2) Creativity of students (3), student learning (4), the student's response to learning that followed.

From the analysis of data for three cycles show that: (1) adherence to teachers in managing learning reaches the percentage level of achievement $84 \%$ or there is the category of "very good (2) the activity of students following study reached the category of" effective ", (3) the creativity students demonstrate $100 \%$ of students creative, (4) the results of student learning of cognitive domains with an average grade 84 the realm of attitudes with an average of 88 , and psychomotor with an average of 81 categories completed, and the thoroughness of the individual reaches $92 \%$ with the category of "complete", (5) the response of students in the following study reached the level of "positive" or the categories (Happy, New, Attractive, and Yes).

Based on the discussion of the results of research and data analysis can be concluded that an increase in creativity and student learning outcomes to the application of scientific approach.

Keywords: Scientific Approach, Creativity, Learning Outcomes. 


\section{PENDAHULUAN}

Berdasarkan Undang-Undang Nomor 20 tahun 2003 tentang Sistem Pendidikan Nasional pasal 36 ayat (2) menegaskan bahwa: Kurikulum pada semua jenjang dan jenis pendidikan dikembangkan dengan prinsip diverifikasi sesuai dengan satuan pendidikan, potensi daerah dan peserta didik. Atas dasar pemikiran tersebut, maka perlu dikembangkan Kurikulum Tingkat Satuan Pendidikan (KTSP), sebagai dasar dan pedoman bagi guru untuk menggunakan metode yang menarik dan bisa meningkatkan hasil belajar siswa dalam proses belajar yaitu pendekatan saintifik. Dalam KTSP Sekolah dasar memuat 8 mata pelajaran ditambah muatan lokal, yang diantaranya terdapat mata pelajaran IPA.

Dengan adanya pedoman tersebut maka pembelajaran IPA di sekolah dasar akan sesuai dengan kehidupan sehari-harinya. Siswa akan menerapkan teori yang termuat dalam pembelajaran IPA sebagaimana tujuan dari mata pelajaran IPA yang berdasarkan Kurikulum satuan pendidikan agar siswa memiliki kemampuan, 1) memeroleh keyakinan terhadap kebesaran Tuhan yang Maha Esa berdasarkan keberadaan, keindahan, dan keteraturan alam ciptaan-Nya, 2) mengembangkan pengetahuan dan pemahaman konsep-konsep IPA yang bermanfaat yang dapat diterapkan dalam kehidupan sehari-hari, 3) mengembangkan rasa ingin tahu, sikap positif dan kesadaran tentang adanya hubungan yang saling mempengaruhi antara IPA, Lingkungan, Teknologi dan Masyarakat; 4) mengembangkan keterampilan proses untuk menyelidiki alam sekitar, memecahkan masalah dan membuat keputusan; 5) meningkatkan kesadaran untuk menghargai alam dan segala keteraturanya sebagai salah satu ciptaan Tuhan. (Depdiknas Ditjen manajemen Dikdasmen Ditjen pembinaan TK dan SD 2007:13-14).

Berdasarkan hàl tujuan didepan bahwa pembelajaran IPA secara jelas dan tegas memberikan informasi bahwa pembelajaran IPA tidak melalui hanya sebatas pemindahan pengetahuan dari guru kepada siswa, akan tetapi menjadi suatu kewajiban bahwa pembelajaran IPA harus melalui penyelidikan (inkuri ilmiah), dan melalui penerapan konsep-konsep IPA dalam bentuk merancang dan membuat suatu karya atau produk. Dengan pembelajaran IPA seperti ini maka akan memberi arti dan kebermaknaaan hasil belajar bagi diri siswa dalam menjalani kehidupannya dan salah satu pembelajaran agar siswa lebih dituntut siswa belajar lebih aktif terdapat pada pembelajaran IPA. Belajar aktif merupakan salah satu hal penting untuk menunjang keberhasilan siswa dalam memperoleh hasil belajar yang optimal dan menggembirakan. Pada tahun 2009 indonesia menempati peringkat bawah 10 besar dari 65 negara PISA (Programme For International Student Assesment). Selain itu juga menurut analisis hasil TIMSS tahun 2007 dan 2011 di bidang IPA menunjukkan siswa Indonesia hanya mampu mencapai level menengah, dari analisis tersebut disimpulkan bahwa apa yang diajarkan kepada siswa indonesia berbeda dengan apa yang diajarkan atau diujikan ditingkat internasional.

Faktor lain penyebab menurunya kemampuan daya serap siswa dalam memahami dan menguasai materi pembelajaran IPA yang relatif rendah dicapai siswa disebabkan antara lain yaitu strategi mengajar guru yang hanya menoton (teacher center). Serta bahan ajar yang diberikan masih hafalan mengenai konsep tanpa memberikan pemahaman terhadap konsep tersebut. Guru yang mengajar pelajaran IPA harus melatih diri untuk lebih kreatif agar dapat memberikan semangat siswa dalam mencapai tujuan pembelajaran. Salah satu cara untuk meningkatkan hasil belajar siswa dapat dilakukan dengan cara memilih metode atau pendekatan yang sesuai dengan karakteristik mata pelajaran. Sebab jika guru tidak kreatif akan menyebabkan menurunya semangat dalam menerima pelajaran dari gurunya, sehingga hasil belajar menurun.

Siswa menganggap dalam pelajaran IPA sangat sulit dipahami dan dimengerti ini terlihat dari proses pembelajaran dan hasil analisis hasil belajar menunjukkan nilai sangat rendah begitu halnya dengan kreativitas dimana siswa hanya terfokus pada jawaban pada buku tanpa mengembangkan ide dan gagasan yang lebih banyak. Oleh karena itu perlu pendekatan atau strategi pembelajaran untuk menyelesaikan permasalahan tersebut yaitu dengan menerapkan pendekatan saintifik (scientific approach). Dimana merupakan suatu proses pembelajaran melalui pengamatan, bertanya, mencoba, kemudian menalar atau mengolah data informasi, menyajikan data atau informasi dilanjutkan Cengan menganalisis, kemudian menyimpulkan.

\section{METODE}

Penelitian ini dilakukan dengan menggunakan rancangan penelitian tindakan kelas (classroom action research) yang terdiri dari tiga siklus bertujuan untuk mengetahui bagaimana suatu pendekatan pembelajaran dan hasil yang ingin dicapai. Adapun tahapan pada penelitian tindakan kelas ini yaitu dimulai pada tahapan perencanaan, pelaksanaan, pengamatan, dan refleksi. (Kemmis\& Taggart,1992). Tindakan yang diterapkan adalah pendekatan saintifik melalui lima tahapan yaitu 
mengamati, mencoba, menalar, menanya, dan mengomukasikan.

Instrumen pengumpulan data yang digunakan dalam penelitian ini adalah observasi, tes hasil belajar dan tes kreativitas, angket siswa serta menggunakan sensivitas butir soal untuk mengetahui pengaruh terhadap butir soal. Instrumen ini memiliki tujuan untuk mengetahui tingkat kemampuan siswa dalam mengikuti pembelajaran.

Subjek penelitian ini adalah siswa kelas V SD Negeri 12/30 Kanaungan , Kab. Pangkep semester 2 tahun ajaran 2014/2015 yang berjumlah 26 orang, yang terdiri dari 12 orang siswa laki-laki dan 14 orang siswa perempuan. Proses penelitian ini melibatkan guru kelas V yang menjadi mitra peneliti dalam menerapkan pembelajaran dengan pendekatan saintifik untuk meningkatkan kreativitas dan hasil belajar siswa dalam mata pelajaran IPA kelas V SD negeri 12/30 Kanaungan, Kab. Pangkep.

Data keterlaksanaan pembelajaran guru dikumpulkan dengan menggunakan lembar observasi guru dan siswa, angket respon siswa dikumpulkan dengan menggunakan lembar angket respon siswa. Data kreativitas belajar siswa dikumpulkan dengan menggunakan tes kreativitas siswa sedangkan data hasil belajar siswa dikumpulkan dengan menggunakan te objektif dan tes uraian. Tes uraian digunakan untuk mengetahui pemahaman materi siswa dengan tingkatan yang lebih tinggi (C1-C6) daripada sekedar ingatan.

\section{HASIL DAN PEMBAHASAN}

\section{Siklus I}

Data hasil keterlaksanaan pembelajaran pada siklus I menunjukkan persentase keberhasilan mencapai $59 \%$ termasuk dalam kategori rendah sehingga perlu ditingkatkan. Begitu juga pada pengamatan aktivitas siswa memeroleh 2,25 dengan persentase keberhasilan mencapai 56,25\%, termasuk dalam kategori rendah sehingga perlu ditingkatkan. Kreaivitas siswa menunjukkan terdapat 11 atau $38 \%$ siswa memiliki kategori kreatif dan 15 atau 62\% siswa tidak kreatif dengan $N$-gain score 0,38 berkategori sedang. hasil belajar siswa pada tingkat kognitif siswa memeroleh $38 \%$ siswa tuntas, dengan $\mathrm{N}$-gain score 0,50 atau $50 \%$ dan tingkat sensivitas atau kepekaan memiliki sensivitas diatas 0,3 afektif memeroleh $63 \%$ sedangkan pada tingkat Psikomotor siswa mencapai $61 \%$ dengan kategori "baik". Karena masih banyak kekurangan dalam pembelajaran sehingga perlu diperbaiki dan ditingkatkan. Pada akhir pembelajaran siswa diberikan lembar angket untuk mengetahui respon yang diberikan terhadap pembelajaran. Menunjukkan masih terdapat $23,07 \%$ siswa yang mengalami kesulitan dalam mengikuti pembelajaran sedangkan yang berminat untuk mengikuti pembelajaran sebanyak 26 orang siswa atau $100 \%$, untuk menyelesaikan permasalahan tersebut perlu ditingkatkan pada siklus berikutnya.

\section{Siklus II}

Data hasil keterlaksanaan pembelajaran pada siklus II menunjukkan persentase keberhasilan mencapai $73 \%$ termasuk dalam kategori "baik "sudah menunjukkan peningkatan pada siklus sebleumnya. Begitu juga pada pengamatan aktivitas siswa memeroleh 3,12 dengan persentase keberhasilan mencapai 78,12\%, termasuk dalam kategori baik menunjukkan adanya peningkatan daripada siklus sebelumnya disebakan adanya cara mengajar guru sudah mulai baik. Kreativitas siswa menunjukkan terdapat 20 atau $76 \%$ siswa memiliki kategori kreatif dan 6 atau 23\% siswa tidak kreatif dengan $N$-gain score 0,60 berkategori "sedang". Sedangkan hasil belajar siswa pada tingkat kognitif siswa memeroleh $76 \%$ siswa tuntas, dengan $\mathrm{N}$-gain score 0,56 atau $56 \%$ katergori "sedang"dan tingkat sensivitas atau kepekaan memiliki Sensivitas diatas 0,3 Afektif memeroleh $72 \%$ dengan kategori "baik". Sedangkan pada tingkat Psikomotor siswa mencapai $71 \%$ dengan kategori "baik". Karena masih banyak kekurangan dalam pembelajaran sehingga perlu diperbaiki dan ditingkatkan. Pada akhir pembelajaran siswa diberikan lembar angket untuk mengetahui respon yang diberikan terhadap pembelajaran. Menunjukkan masih terdapat $53,85 \%$ siswa yang mengalami kesulitan dalam mengikuti pembelajaran. Walaupun masih ada beberapa siswa yang menglami kesulitan dalam pembelajaran dengan menerapkan pendekatan saintifik tetapi masih $100 \%$ siswa berminat untuk mengikuti pembelajaran dengan menggunakan pendekatan saintifik sehingga perlu dilanjutkan pada siklus Berikutnya yaitu siklus III.

\section{Siklus III}

Data hasil keterlaksanaan pembelajaran pada siklus II menunjukkan persentase keberhasilan mencapai $84 \%$ termasuk dalam kategori "sangat baik" hasil tersebut sudah memenuhi ketuntasan keberhasilan yaitu $80 \%$. Begitu juga pada pengamatan aktivitas siswa secara keseluruhan sudah mencapai ketuntasan keberhasilan yaitu $80 \%$. Kreativitas siswa menunjukkan terdapat 26 atau $100 \%$ siswa kreatif dengan $\mathrm{N}$-gain score 0,72 berkategori "tinggi". Sedangkan pada Hasil Belajar Siswa pada tingkat kognitif siswa memeroleh 92,30\% siswa tuntas dengan rata-rata kelas siswa sebesar $83,76 \%$, dengan $N$-gain score 0,71 atau $71 \%$ katergori "tinggi"dan tingkat sensivitas atau kepekaan memiliki Sensivitas diatas 0,3 Afektif memeroleh $88 \%$ tuntas dengan kategori "sangat baik". Sedangkan pada tingkat Psikomotor siswa mencapai $81 \%$ dengan kategori "sangat baik". Sehingga tidak perlu dilanjutkan paa siklus berikutnya. Pada akhir 
Penerapan Pendekatan Saintifik Untuk Meningkatkan Kreativitas dan Hasl Belajar Siswa dalam Mata Pelajaran IPA Kelas V SDN 12/30 Kanaungan Kab. Pangkep

Nur Alamsyah

pembelajaran siswa diberikan lembar angket untuk mengetahui respon yang diberikan terhadap pembelajaran menunjkkan hanya satu orang siswa dai seluruh siswa yang memiliki kesulitan untuk mengikuti pembelajaran dengan pendekatan saintifik

\section{Hasil Tindakan Kelas Siklus I-III}

Berikut akan disajikan hasil pengamatan keterlakasanaan pembelajaran dari siklus I-III dalam bentuk tabel dan diagram berikut.

Tabel 4.4

Data Keterlaksanaan Guru Siklus I-III

\begin{tabular}{|c|c|c|c|c|}
\hline \multirow[b]{2}{*}{ No } & \multirow[b]{2}{*}{ Aspek yang diamati } & \multicolumn{3}{|c|}{ Persentase keberhasilan (\%) } \\
\hline & & Siklus I & Siklus II & Siklus III \\
\hline 1 & $\begin{array}{l}\text { Membimbing siswa dalam } \\
\text { pengamatan }\end{array}$ & 62,5 & 75 & 75 \\
\hline 2 & $\begin{array}{l}\text { Membimbing siswa dalam } \\
\text { mengadakan percobaan }\end{array}$ & 50 & 75 & 87,5 \\
\hline 3 & Membimbing siswa dalam menalar & 50 & 62,5 & 87,5 \\
\hline 4 & Membimbing siswa dalam bertanya & 50 & 62,5 & 75 \\
\hline 5 & $\begin{array}{c}\text { Membimbing siswa dalam } \\
\text { menyajikan materi }\end{array}$ & 75 & 75 & 87,5 \\
\hline 6 & Penggunn media & 75 & 75 & 87,5 \\
\hline 7 & Alokasi Waktu & 50 & 87,5 & 87,5 \\
\hline & Persentase ketuntasan (\%) & 59 & 73 & 84 \\
\hline
\end{tabular}

Sedangkan untuk persentase keberhasilan semua aspek dari siklus I hingga siklus III dapat kita lihat pada grafik sebagai berikut:

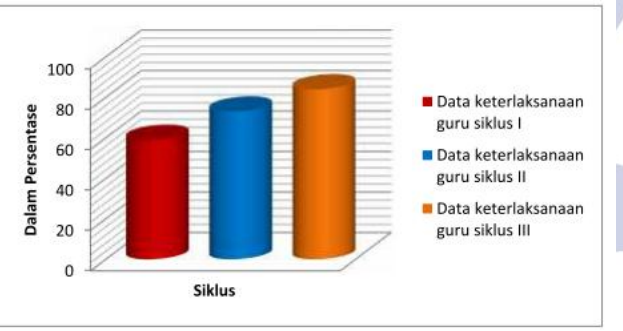

Gambar grafik 4.15 Data keterlaksanaan Guru Siklus I-III

Pada bagian berikut akan disajikan hasil pengamatan aktivitas siswa selama berlangsungnya pembelajaran siklus I-III dalam bentuk tabel

Tabel 4.5

Aktivitas Siswa Siklus I-III

\begin{tabular}{|c|c|c|c|c|}
\hline \multirow[b]{2}{*}{ No } & \multirow[b]{2}{*}{ Aspek yang diamati } & \multicolumn{3}{|c|}{ Persentase keberhasilan (\%) } \\
\hline & & Siklus I & Siklus II & Siklus III \\
\hline 1. & A. Memperhatikan penjelasan Guru & 75 & 87,5 & 100 \\
\hline 2. & B. Melakukan Pengamatan & 50 & 75 & 100 \\
\hline 3. & $\begin{array}{l}\text { C.Melakukan diskusi kelompok } \\
\text { untuk menganalisis hasil pengamatan }\end{array}$ & 50 & 75 & 100 \\
\hline 4. & $\begin{array}{l}\text { D.Bertanya atau menanggapi } \\
\text { pertanyaan yang diberikan baik } \\
\text { sesama siswa maupun dari guru? }\end{array}$ & 37,5 & 87,5 & 87,5 \\
\hline 5. & $\begin{array}{l}\text { E.Mencoba mengumpulkan } \\
\text { informasi }\end{array}$ & 37,5 & 75 & 87,5 \\
\hline 6. & $\begin{array}{l}\text { F.Membuat laporan hasil kerja } \\
\text { kelompok }\end{array}$ & 50 & 75 & 87,5 \\
\hline 7. & $\begin{array}{l}\text { G. Mempersentasikan hasil kerja } \\
\text { kelompok }\end{array}$ & 75 & 75 & 87,5 \\
\hline 8. & H. Membuat kesimpulan & 50 & 75 & 87,5 \\
\hline & Persentase ketuntasan (\%) & 62,5 & 78,12 & 94 \\
\hline
\end{tabular}

Selain disajikan dalam bentuk tabel untuk mengetahui persentase keberhasilan semua aspek dari siklus I hingga siklus III dapat kita lihat pada gambar grafik 4.16 berikut.

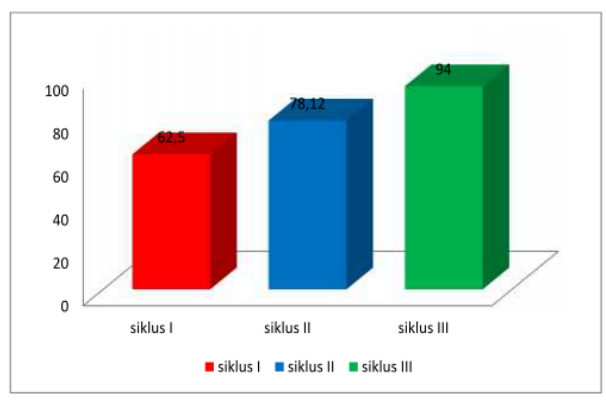

Gambar grafik 4.16 Data Aktivitas Siswa Siklus I-III

Dengan melihat diagram 4.16 di atas, maka dapat diketahui bahwa terjadi peningkatan tiap siklusnya. Pada siklus I semua aspek memeroleh persentase keberhasilan sebesar $62,5 \%$ pada siklus II, semua aspek memeroleh persentase keberhasilan sebesar 78,12\% (terjadi peningkatan sebesar 9,62\%). Pada siklus III, semua aspek memeroleh persentase keberhasilan sebesar 94\% (terjadi peningkatan sebesar 21,88\%). Peningakatan keberhasilan terjadi karena adanya aktivitas guru yang meningkat sehingga berpengaruh terhadap hasil belajar psikomotor siswa.

Berikut akan disajikan data hasil kreativitas siswa selama berlangsungnya pembelajaran siklus I-III dalam bentuk tabel 4.10

Tabel 4.9

Hasil Tes Kreativitas Siklus I-III

\begin{tabular}{|c|c|c|c|}
\hline \multirow{2}{*}{ No } & \multirow{2}{*}{$\begin{array}{c}\text { Persentase } \\
\text { Keberhasilan (\%) }\end{array}$} & \multicolumn{2}{|c|}{ Kategori } \\
\cline { 3 - 4 } & & Kreatif & Tidak kreatif \\
\hline 1. & Siklus I & $58 \%$ & $42 \%$ \\
\hline 2. & Siklus II & $77 \%$ & $23 \%$ \\
\hline 3. & Siklus III & $100 \%$ & $0 \%$ \\
\hline
\end{tabular}

Sumber :diolah peneliti

Selain disajikan dalam bentuk tabel, untuk mengetahui persentase keberhasilan semua kategori dari siklus I-III dapat kita lihat pada diagram sebagai berikut.

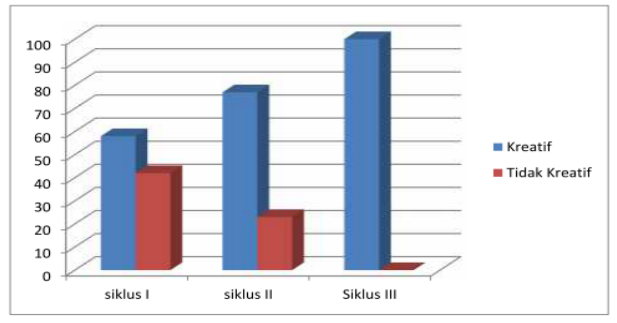

Gambar grafik 4.20 Hasil Tes Kreativitas Siswa Siklus I-III 


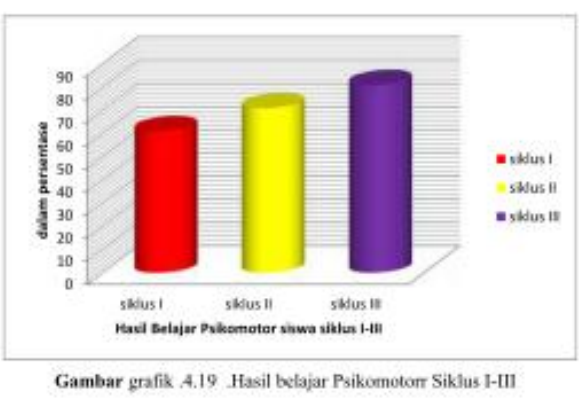

Selain disajikan dalam bentuk tabel untuk persentase keberhasilan semua aspek dari siklus I hingga siklus III dapat kita lihat pada diagram sebagai berikut

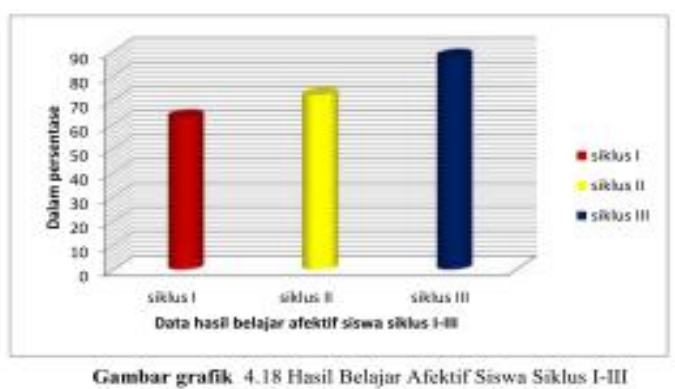

Dengan melihat diagram 4.17 diatas, maka dapat dikatahui bahwa terjadi peningkatan tiap siklusnya. Pada siklus I, semua aspek memeroleh persentase keberhasilan sebesar $63 \%$. Pada siklus II, semua aspek memeroleh persentase keberhasilan sebesar $72 \%$ (terjadi peningkatan sebesar 9\%. Pada siklus III, semua aspek memeroleh persentase keberhasilan sebesar $88 \%$ (terjadi peningkatan sebesar 16\%). Peningkayan keberhasilan terjadi karena adanya aktivitas guru yang meningkatn sehingga berpengaruh terhadap hasil belajar afektif siswa.

3) Hasil Belajar Psikomotor Siswa Siklus I-III

Berikut disajikan dalam data psikomotor siswa selama proses pembelajaran siklus I-III

Tabel 4.19

Data Hasil Belajar Psikemoter Siswa Siklus I-III

\begin{tabular}{|c|l|c|c|c|}
\hline \multirow{2}{*}{ No } & \multirow{2}{*}{ Rincian tugas } & \multicolumn{3}{|c|}{ Persentase Keberhasilan (\%) } \\
\cline { 3 - 5 } & & Siklus & Sislus & Siklus \\
\hline 1 & & 1 & II & III \\
\hline 2 & Menyiapkin peralatan & 60 & 72 & 82 \\
\hline 3 & Ketepatan Urutan/langkah kerja & 60 & 72 & 80 \\
\hline 4 & Keruntutan laporan/ hasil kerja & 63 & 69 & 81 \\
\hline & Persentise kefuntasan & 61 & 71 & 81 \\
\hline
\end{tabular}

Sumber:diolah peneliti

Jersentase keberhasılan semua aspek darı sıklus 1-III dapat kita lihat pada diagram sebagai berikut.

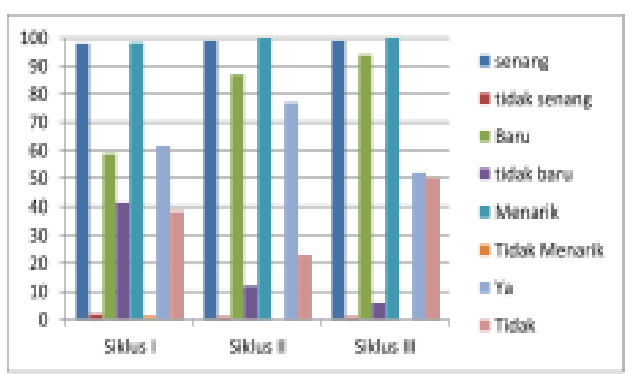

Gambar grafik , 4.21 Data Respon Siswa Siklus I-III 
Penerapan Pendekatan Saintifik Untuk Meningkatkan Kreativitas dan Hasl Belajar Siswa dalam Mata Pelajaran IPA Kelas V SDN 12/30 Kanaungan Kab. Pangkep

Nur Alamsyah

\section{PENUTUP}

\section{Simpulan}

Berdasarkan hasil penelitian dan pembahasan diskusi penelitian ini, dapat dikemukakan kesimpulan sebagai berikut:

1. Keterlaksanaan Pembelajaran

Keterlaksanaan pembelajaran dengan penerapan pendekatan saintifik , Pada setiap siklusnya menunjukkan peningakatan, peningkatan tersebut berdampak positif terhadap tercapainya tahapan-tahapan dalam pembelajaran yaitu mendorong siswa untuk melakukan pengamatan, mengadakan percobaan, membing siswa dalam menalar, dan mendorong siswa untuk bertanya serta menyajikan materinya dari hasil diskusi kelompoknya kesemuanya ini dapat mendorong siswa untuk memiliki rasa keingintahuan.

\section{Aktivitas siswa}

Aktivitas pada penelitian ini secara umum dari seluruh aspek menunjukkan peningkatan, karena semua aspek terlaksana dengan baik. Pada siklus I rata-rata aktivitas siswa 2,25 dengan pencapaian persentase ketuntasan sebesar $56,25 \%$. Siklus II memeroleh rata-rata aktivitas siswa 3,12 dengan pencapaian persentase ketuntasan sebesar $78,12 \%$. Sedangkan pada siklus III memeroleh nilai rata-rata 3,8 dengan pencapaian persentase ketuntasan sebesar $94 \%$. Hal berarti dengan diterapkanya pendekatan saintifik terjadi peningkatan yang sangat baik.

\section{Kreativitas siswa}

Hasil tes kreativitas siswa menunjukkan dimulai pada tes awal siswa hanya terdapat 2 siswa yang berkategori kreatif atau hanya sebesar $7,69 \%$, pada siklus I menunjukkan perubahan terdapat sudah 15 siswa yang memiliki kategori kreatif atau 57,69\% ada peningkatan $50 \%$ dari tes awal siswa. Pada siklus II menunjukkan peningkatan secara signifikan terdapat 20 siswa sudah berkategori kreatif atau $76,92 \%$, terdapat peningkatan dari siklus I sebesar 19,23\%. Sedangkan pada siklus III menunjukkan seluruh siswa sudah berkategori kreatif atau $100 \%$ siswa kreatif. Dengan demikian pembelajaran ini dengan menggunakan penerapan pendekatan saintifik dinyatakan tuntas.

\section{Hasil Belajar Siswa}

Hasil belajar siswa dari mulai siklus I hingga siklus III menunjukkan peningkatan . dengan nilai rata-rata siklus I sebesar 67, naik menjadi 77 pada siklus II dan menjadi 84. Sementara ketuntasn individu naik secara signifikan dari siklus I sebesar 38\%, pada siklus II menjadi $76 \%$ atau naik $38 \%$. Sedangkan pada siklus III menjadi $92 \%$ atau meningkat $16 \%$ dari siklus II dan hanya 2 siswa dari 26 siswa yang belum tuntas atau

hanya $7,69 \%$. Dengan demikian pembelajaran ini dinyatakan tuntas.

5. Respon siswa

Pada perubahan respon siswa dalam menerima materi pembelajaran. Perubahan tersebut menggambarkan bahwa siswa merasa senang untuk mengikuti pembelajaran dengan pendekatan saintifik untuk materi lain. Reapon siswa dapat dinyatakan "Positif": karena memenuhi unsur: Senang, Baru, Menarik, dan Ya atau setuju dengan penerapan pendekatan saintifik.

\section{Saran}

Berdasarkan kesimpulan hasil penelitian serta kelemahan dan hambatan selama penelitian maka peneliti dapat memberikan saran-saran sebagai berikut.

1. Bagi siswa yang terutama pada kategori yang belum tuntas perlu diberi dorongan dan motivasi yang lebih agar mereka dapat lebih tertarik mengikuti kegiatan pembelajaran.

2. Berdasarkan hasil belajar yang dicapai dengan diterapkanya pendekatan saintifik dapat dijadikan alternatif untuk di implementasikan di sekolah dasar pada materi yang berbeda dan relevan menggunakan perangkat pembelajaran yang lebih baik.

3. Sebaiknya dalam pembelajaran IPA khususnya agar lebih banyak melibatkan siswa dalam memanfaatkan media pembelajaran agar dapat menciptakan situasi pembelajaran yang menyenangkan, agar dapat melatih kreativitas siswa dalam berdikusi dan meningkatkan rasa ingin tahu untuk berfikir kritis dan kreatif.

4. Guru dalam merencanakan serta melaksanakan pembelajaran, sebisa mungkin dalam menerapkan metode dan pendekatan dalam pembelajaran yang ada kaitanya dengan materi yang diajarkan kepada siswa untuk melibatkan lingkungan sekitar sebagai media secara langsung agar siswa dapat mengetahui kehidupan yang ada sekitarnya.

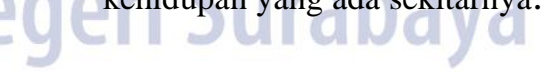

\section{DAFTAR PUSTAKA}

Amirah Siti,(2014). Buku Analisis Penilaian Kelas V SD Negeri 12/30. Kanaungan. 2014.

Arikunto, Suharsimi. (1993). Dasar-dasar Evaluasi Pendidikan. Jakarta: Bumi Aksara

Arikunto, Suharsimi. (2006). Prosedur Penelitian Suatu Pendekatan Praktek. Jakarta: Rineka Cipta.

Atsnan, M.F.(2013). "Penerapan Pendekatan Scientific Dalam Pembelajaran Matematika Smp Kelas VII Materi Bilangan (pecahan) di Jurusan Pendidikan 
Matematika FMIPA UNY". Makalah dipresentasikan dalam Seminar Nasional Matematika dan Pendidikan Matematika untuk indonesia yang lebih baik, Yogyakarta, pada tanggal 9 November 2011.

Bloom, Karthwohl, (1973). Taxonomy of Educational Objectives. New York: Longman.

BSNP. (2006). Model KTSP dan Model Silabus Mata Pelajaran SD/MI. Jakarta: BP. Cipta Jaya.

Campbell, David. (1992). Take the Road to Creativity and Get of Your Dead End (terjemahan Sadman Mangunhardjana). Yogyakarta: Kanisius.

Carin \& Sund. (1975) Teaching Science Through Discover.Charles E. Merril Publising company

Carin \& Sund.( 1993). Metode Pembelajaran Terpadu dalam Teori dan Praktek. Jakarta:PT Remaja Rosdakarya.

Dwi Yasa Arnelia. (2014). Penguasaan Konsep dan Kreatifitas Siswa Setelah Diajarkan Dengan Penekatan Saintifik (Scientifik Approach). (Tesis Magister Pendidikaan tidak dipublikasikan). Universitas Negeri Surabaya.

Daryanto, (2007). Evaluasi Pendidikan. Jakarta: PT. Rineka Cipta,

Daryanto, (2014). Pendekatan Pembelajaran Saintifik Kurikulum 2013. Yogyakarta: Gava Media

Depdikbud. (1996). Kamus Besar Bahasa Indonesia, Jakarta : Balai Pustaka,

Depdiknas, (2007). Peraturan Menteri Pendidikan Nasional Republik Indonesia No.41 Tahun 2007 Tentang Standar Proses Untuk Satuan Pendidikan Dasar Dan Menengah. Jakarta: Badan Standar Nasional Pendidikan, Departemen Pendidikan Nasional.

Downing, J.P, (1997). Creative Teaching: Ideas to Boost Student Interest.colarado: libraries Unlimited.

Florence B. (2013).Creative Lerning Terjemahan. Bandung .PT.Nusa Media.

Glass.A.L dan Holyoak.K.J. (1986). Cognition. Second edition. Mc Graw-Hill international, Auckland.

Hamalik.Oemar, (2001). Proses Belajar Mengajar. Jakarta:Bumi Aksara.

Hidayah. (2013). Pengertian dan Langkah-Langkah Saintifik. $\quad$ zhttp://www.nurulhidayah.net/879pengertian-dan-langkah-pembelajaran saintifik.html\#! prettyPhoto diakses tanggal 30 November 2014

Hosnan.M.D, (2014). Pendekatan Saintifik Dan Kontekstual Dalam Pembelajaran Abad 21 Kunci Sukses Implementasi Kurikulum 2013.Jakarta:PT. Ghalia Indonesia.

Huda, M. (2013). Model-model pengajaran dan pembelajaran. Malang: Pustaka pelajar.

Hurlock. Elizabeth B. (1978).Perkembangan Anak Jilid I Edisi 6.Jakarta.Erlangga

Ibrahim,M. (2005). Assesment Berkelanjutan. Surabaya: Unesa University Press.

Indarti, (2008). Penelitian tindakan kelas (PTK) dan penulisan ilmiah (prinsip-prinsip dasar, langkahlangah dan implementasinya). Surabaya: UNESA university Press.

Kardi,dan Nur, (1994). Pengajaran Langsung. Surabaya: Unesa-University Press.

Kemendikbud. (2013). Pengembangan Kurikulum 2013.Jakarta: Puskur Kemendikbud.

Kemendikbud. (2013). Permendikbud no.81 A 2013 tentang implementasi kurikulum.Jakarta: kementerian Pendidikan dan Kebudayaan.

Kemmis, S \& Mc. Taggart,R. (1992). The Action Research Planner. Australia: deakin University Press.

Kunandar. (2013). Langkah Mudah Penelitian Tindakan Kelas Sebagai Pengembangan Profesi Guru. Jakarta: PT. Raja Grafindo Persada.

Majid, A.(2014). Pembelajaran Tematik Terpadu. Remaja Rosda Karya. Bandung.

Munandar,U. (2012). Pengembangan Kreativitas Anak Berbakat. Jakarta: Rineka Cipta.

Nurhadi. (2014). Peningaktan Motivasi Dan Kreatifitas Siswa Dalam Memecahkan Masalah Melalui Model Arcs Pada Mata Pelajaran IPS Kelas V SDN Gunongsari 1 Sampang (Tesis Magister Pendidikan Tidak Dipublikasikan). Universitas Negeri Surabaya.

Pidarta. Made. (2009). Wawasan Pendidikan. Surabaya: Unesa University Press.

Prihantoro,L.,Wirasasmita,O.,dan Liliasari. (1986). IPA Terpadu. Jakarta: Depdikbud Universitas Terbuka.

Program Pascasarjana Universitas Negeri Surabaya. (2014). Pedoman Penulisan Tesis dan Disertasi.Surabaya 
Penerapan Pendekatan Saintifik Untuk Meningkatkan Kreativitas dan Hasl Belajar Siswa dalam Mata Pelajaran IPA Kelas V SDN 12/30 Kanaungan Kab. Pangkep

Nur Alamsyah

Purwanto, (2007). Psikologi Pendidikan. Bandung.PT. Remaja Rosdakarya.

Ratumanan, T.G,Laurens,T. (2011). Penilaian Hasil Belajar pada Tingkat Satuan Pendidikan Edisi 2. Ambon: Unesa University Press.

Riyanto,Yatim. (2010). Paradigma Baru Pembelajaran.Kencana Prenada Media Group. Jakarta.

Rudolph,J.L. (2005). "Epistemology for the Masses: TheOrigins of "The Scientific Method" in American Schools" Vol. 45,341-376.

Rustaman, N.Y.(2005). Strategi Belajar Mengajar Biologi. Malang: Universitas Negeri Malang.

Santrock, J.W. (2007). Psikologi Pendidikan (edisi kedua) penerjemah.tri Wibowo B.S) Jakarta: Kencana.

Santrock, J.W. (2009). Psikologi Pendidikan (edisi tiga, jilid 2). Jakarta: Salemba .

Siswono. (2008). Model Pembelajaran Matematika Berbasis Pengajuan Dan Pemecahan Masalah Untuk Meningkatkan Kemampuan Berfikir Kreatif. Unesa University Press: Surabaya

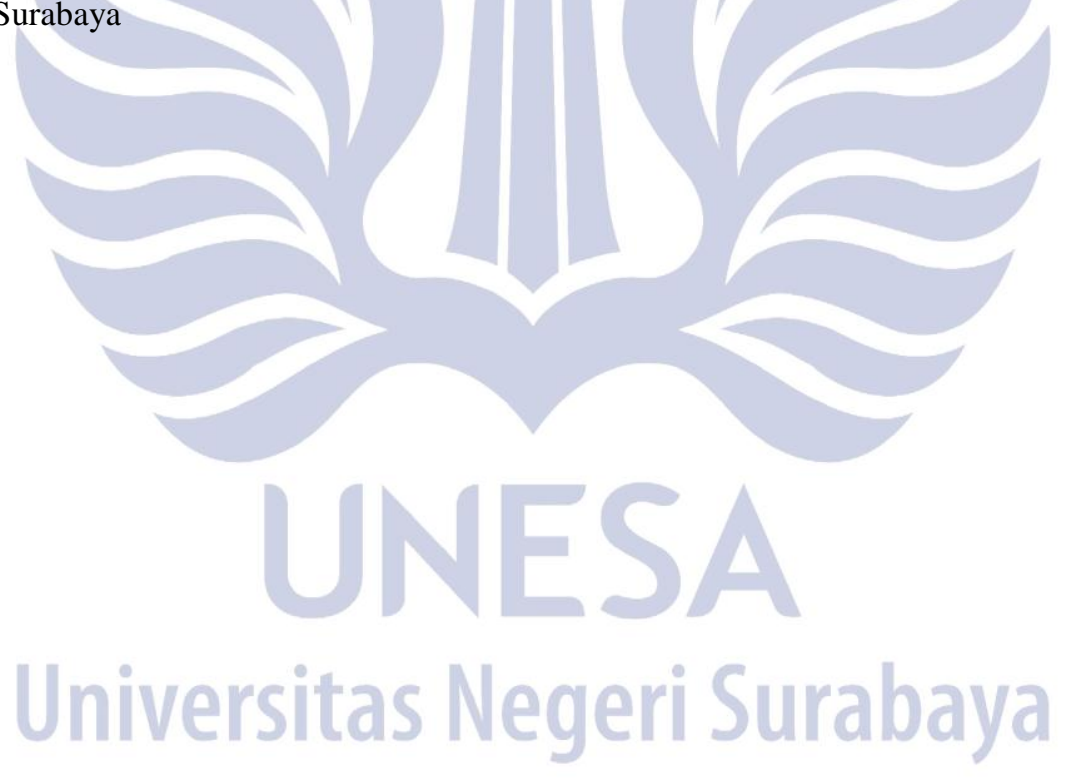

